\title{
Pemanfaatan Asam Humat dari Sampah Organik Sebagai Adsorben pada Limbah Cair Sintesis Timbal (Pb)
}

\author{
Maimunawaro, Sazila Karina Rahman, Chairul Irawan * \\ Program Studi Teknik Kimia, Fakultas Teknik, Universitas Lambung Mangkurat, Jl. A. Yani KM. 36 \\ Banjarbaru, 70714, Indonesia \\ *e-mail: cirawan@ulm.ac.id
}

\begin{abstract}
Abstrak. Industri pelapisan logam disamping memiliki konstribusi bagi perekonomian Indonesia, namun dalam prosesnya menghasilkan limbah cair yang memberikan dampak negatif bagi lingkungan karena mengandung logam berat. Salah satu teknik pengolahan limbah cair yaitu adsorpsi menggunakan asam humat dari ekstraksi sampah organik yang dijadikan adsorben. Kelebihan proses adsorpsi ini ialah pengerjaannya mudah, biaya relatif murah, relatif aman dari kontaminasi zat-zat kimia, serta tidak memberikan polusi berarti bagi lingkungan. Ekstraksi asam humat dari sampah organik berlangsung secara bertahap menggunakan proses ekstraksi dengan 1 L NaOH dengan variasi pelarut 0,1 N dan 0,5 N. Karakterisasi sebelum dan sesudah ekstraksi menggunakan Fourier-transform infrared spectroscopy (FTIR), X-Ray Diffraction (XRD), dan Scanning Electron Microscope (SEM), masing-masing untuk mengetahui gugus fungsional, struktur kristal, serta struktur morfologi pada asam humat. Proses adsorpsi menggunakan asam humat sebagai adsorben dilakukan secara batch dengan massa adsorben 1 g/L, kecepatan pengadukan 150 rpm, temperatur ruang dan pH 6,7-7,0 selama 1 jam. Analisa setelah adsorpsi menggunakan metode Atomic Absorption Spectrofotometer (AAS) untuk uji kadar timbal (Pb (II)). Hasil adsorpsi timbal (Pb) pada kedua variasi pelarut adsorben dengan pH awal 6,7-7,0 memiliki keefektifan masing-masing mencapai hampir 98\%.
\end{abstract}

Kata kunci: adsorben, asam humat, ekstraksi, sampah organik.

Abstract. Removal of Lead (II) of Synthetic Wastewater Using Humic Acid Extracted from Organic Waste As Adsorbent. Metal plating Industry mining productions contribute to the growth of the Indonesian economy, but during the processes usually create a negative environmental impact such as heavy metals. The adsorption method is one of various methods for wastewater treatment. The humic acid as adsorbent in the adsorption method had been extracted from organic waste. The advantages of this method are simple, cheap and secure from chemical contaminant. The extraction of humic acid from organic waste takes place gradually using $1 \mathrm{~L} \mathrm{NaOH}$ with a variety of solvents of $0.1 \mathrm{~N}$ and $0.5 \mathrm{~N}$. The humic acid before and after treatment was characterized using Fourier-transform infrared spectroscopy (FTIR) X-Ray Diffraction (XRD) and Scanning Electron Microscope (SEM). The adsorption process was carried out in batch experiment with mass adsorbent of $1 \mathrm{~g} / \mathrm{L}$, stirring speed of $150 \mathrm{rpm}$, room temperatur, pH around 6.7-7.0 for 1 hour. The result showed by Atomic Absorption Spectroscopy (AAS) analysis characterize that adsorption lead (II) in several adsorbent concentrations at pH 6.7-7.07 has effectiveness $98 \%$.

Keywords: adsorbents, extraction, humic acid, organic waste.

\section{Graphical Abstract}

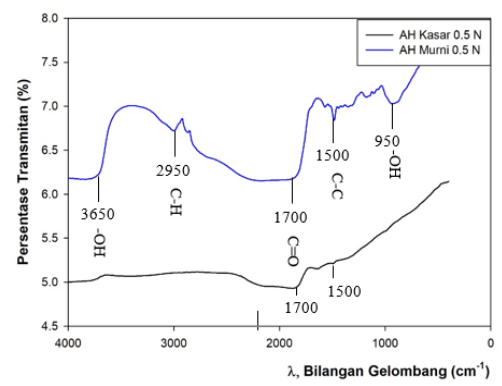

\section{Pendahuluan}

Distribusi pencemaran semakin luas dengan semakin berkembang dan tumbuh pesatnya industri. Beberapa dari industri tersebut menghasilkan limbah cair yang mengandung logam berat seperti timbal pada industri pelapisan logam. Industri pelapisan logam dalam proses pencuciannya biasanya menghasilkan logam berat timbal. Tabel 1 memberikan informasi mengenai baku mutu limbah cair yang harus dipenuhi oleh industri pelapisan logam dalam menjalankan kegiatan industrinya (Kementerian LH, 2014).

Logam berat timbal $(\mathrm{Pb}(\mathrm{II}))$ apabila terakumulasi dalam jumlah besar memiliki sifat toksik yang menjadi faktor utama penyebab kerusakan lingkungan sehingga 
diperlukan solusi untuk mengatasi pencemaran tersebut. Salah satu metode untuk mengatasi pencemaran dari limbah industri yaitu menggunakan asam humat pada lingkungan yang tercemar, khususnya pada tanah dan perairan. Asam humat dalam hal ini dapat dipergunakan untuk mengadsorpsi logam berat pada tanah atau perairan yang telah tercemar limbah industri. Asam humat dapat mengadsorpsi logam berat pada kondisi basa, karena asam humat dapat larut pada $\mathrm{pH}$ medium sekitar $\geq 6$ dengan kelarutan asam humat $\geq 95 \%$ (Yunitawati dkk., 2011; Xu dkk., 2021).

Secara umum, asam humat merupakan bahan makromolekul polielektrolit yang memiliki gugus fungsional seperti $-\mathrm{COOH}$, $-\mathrm{OH}$ fenolat maupun $-\mathrm{OH}$ alkoholat. Kemampuan asam humat untuk berikatan dengan ion logam cukup tinggi, karena gugus ini dapat mengalami deprotonasi pada $\mathrm{pH}$ yang relatif tinggi (Boguta dkk., 2019). Asam humat dapat dengan mudah diperoleh dari bahan organik seperti kompos. Kompos merupakan bahan organik yang dihasilkan dari penguraian dan modifikasi sisa organisme dari hewan maupun tumbuhan dengan komposisi yang terkandung di dalamnya diantaranya asam humat, asam fulfat, dan humin.

Asam humat mengandung unsur hara makro seperti $\mathrm{C}, \mathrm{H}, \mathrm{N}$, dan S, terdapat ikatan aromatik dan alifatik, serta tingkat kemasaman yang dipengaruhi oleh kandungan gugus fenol dan karboksil (de Melo dkk., 2016). Asam humat dipilih sebagai adsorben karena keragaman proses interaksi pada gugus fungsi yang dimilikinya untuk berikan dengan beberapa logam seperti Cr, Cu, Fe, Cd, dan Pb (Scaglia dkk., 2013; Yang dkk., 2015; Boguta dkk., 2019; Xu dkk., 2021). Asam humat dapat dipergunakan sebagai adsorben dikarenakan asam humat memenuhi syarat yang umum dimiliki oleh adsorben, yaitu terdapat gugus-gugus fungsi yang bertindak sebagai ligan. Ligan yang terdapat pada asam humat, antara lain; - $\mathrm{COOH},-\mathrm{OH}$ fenolat, dan -OH alkoholat seperti yang terlihat pada struktur molekul asam humat pada Gambar 1 (Hayes, 1998; de Melo dkk., 2016). Ligan-ligan inilah yang bertindak sebagai pendonor pasangan elektron dalam pengikatan kation logam yang terdapat di lingkungan. Proses adsorpsi akan diulas lebih lanjut melalui studi interaksi logam berat timbal $\mathrm{Pb}$ (II) dengan asam humat dalam penelitian ini.

Penelitian ini menggunakan asam humat dari ekstraksi sampah organik menggunakan sampah sayuran pasar yang sebagian besar terdiri dari sampah sayuran dan buah-buahan yang terlebih dahulu dikomposkan, untuk selanjutnya dijadikan adsorben untuk proses adsorpsi logam. Sampah sayuran dan buah-buahan merupakan sampah organik digunakan sebagai sumber asam humat yang mengalami berbagai tahap dekomposisi. Sampah organik berperan dalam pelapukan dan proses dekomposisi mineral tanah, sumber hara tanaman, pembentukan struktur tanah stabil dan pengaruh langsung pada pertumbuhan dan perkembangan tanaman pada kondisi tertentu. Sampah organik mengandung bahan organik yang berpengaruh terhadap sifat fisik, kimia, dan biologi tanah, antaranya sebagai penyedia unsur hara seperti $\mathrm{C}, \mathrm{H}, \mathrm{N}, \mathrm{P}$ dan $\mathrm{S}$ yang penting bagi tanaman, sebagai sumber energi bagi organisme tanah, sebagai penyangga (buffer) terhadap perubahan $\mathrm{pH}$, dapat berikatan dengan logam-logam, serta memiliki kemampuan berkombinasi dengan mineral tanah (Boguta dkk., 2016; de Melo dkk., 2016; Hu dkk., 2018).

Kandungan asam-asam organik seperti kandungan asam humat dan asam fulvat yang dihasilkan dari kompos dapat ditentukan melalui analisis kimia dan karakterisasi material (Mao dkk., 1998). Pemisahan asam humat dari campurannya didasarkan atas kelarutannya dalam asam dan alkali. Pemisahan asam humat melalui proses ekstraksi perlu untuk diketahui dan dipahami supaya memudahkan dalam penentuan kualitas kompos. Dua pertimbangan untuk pemilihan ekstraktan yang cocok didasarkan pada: 1) pengekstrak seharusnya kimia bahan yang diekstrak; dan 2) pengekstrak harus dapat memisahkan asam humat dari campurannya secara kuantitatif. Prosedur yang paling umum digunakan untuk ekstraksi asam humat adalah dengan menggunakan larutan $\mathrm{NaOH}$ pada konsentrasi $0,1 \mathrm{~N}$ dibandingkan menggunakan larutan $\mathrm{NaOH}$ dengan konsentrasi $0,5 \mathrm{~N}$ (Scaglia dkk., 2013).

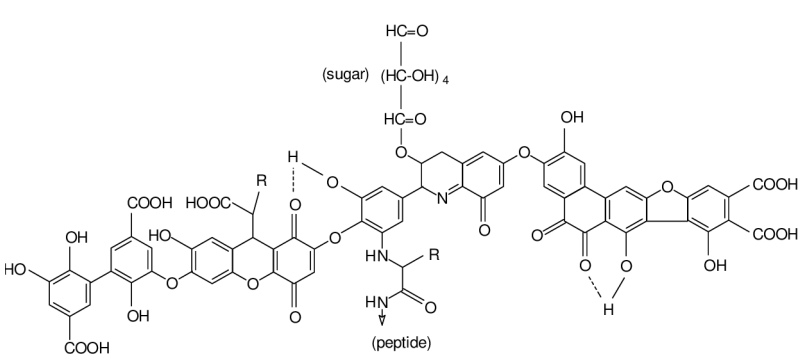

Gambar 1. Model struktur asam humat (dikutip dari Peña-Méndez dkk., 2005)

Tabel 1. Baku mutu limbah cair untuk industri pelapisan logam

\begin{tabular}{ccccc}
\hline Parameter & $\begin{array}{c}\text { Kadar Paling } \\
\text { Tinggi Pelapisan } \\
\text { Logam }(\mathrm{mg} / \mathrm{L})\end{array}$ & $\begin{array}{c}\text { Beban Paling } \\
\text { Tinggi Pelapisan } \\
\text { Logam }\left(\mathrm{g} / \mathrm{m}^{2}\right)\end{array}$ & $\begin{array}{c}\text { Kadar Paling Tinggi } \\
\text { Galvanisasi }(\mathrm{mg} / \mathrm{L})\end{array}$ & $\begin{array}{c}\text { Beban Paling Tinggi } \\
\text { Galvanisasi }\left(\mathrm{g} / \mathrm{m}^{2}\right)\end{array}$ \\
\hline $\mathrm{TSS}$ & 20 & 0,4 & 20 & 0,04 \\
$\mathrm{~Pb}$ & 0,1 & 0,002 & 0,1 & 0,0002 \\
$\mathrm{pH}$ & $6-9$ & & $6-9$ & 2 L per $\mathrm{m}^{2}$ produk pelapisan logam \\
$\begin{array}{c}\text { Kuantitas air } \\
\text { limbah paling } \\
\text { tinggi }\end{array}$ & 20 L per m ${ }^{2}$ produk pelapisan logam & & \\
\hline
\end{tabular}




\section{Metodologi}

2.1. Ekstraksi limbah organik sampah sayuran menghasilkan asam humat

Ekstraksi limbah organik dalam hal ini menggunakan sampah sayuran menjadi asam humat menggunakan prosedur yang diutarakan (Li dkk., 2003) dengan beberapa modifikasi. Sampah sayuran diperoleh dari salah satu pasar di daerah Pelaihari Kalimantan Selatan dicampur dengan kotoran ternak sapi sebagai starter dengan perbandingan massa $2: 1$ dan dimasukan ke dalam tangki pengomposan tertutup berukuran $20 \mathrm{~L}$ dengan lubang aerasi berukuran $1 \mathrm{~cm}^{2}$. Selanjutnya secara rutin setiap dua minggu sekali dilakukan penyiraman kompos dan pengadukan menggunakan air sebanyak $500 \mathrm{~mL}$. Dalam kurun \pm 1 bulan akan terbentuk kompos yang dikecilkan ukurannya dengan cara dipotong dengan ukuran $\pm 5 \mathrm{~cm}$ serta dikeringkan selama 7 hari pada sinar matahari. Kompos kering yang diperoleh dilanjutkan pengeringannya menggunakan oven pada temperatur $40^{\circ} \mathrm{C}$ selama $36 \mathrm{jam}$, didinginkan, dihaluskan dan diseragamkan ukurannya pada 100 mesh. Pada tahap ekstraksi, kompos kering dengan ukuran 100 mesh sebanyak 100 gram dimasukkan ke dalam gelas beker $1 \mathrm{~L}$ dengan variasi ekstraktan $\mathrm{NaOH} 0,1 \mathrm{~N}$ dan 0,5 $\mathrm{N}$. Campuran ini diaduk dengan kecepatan pengadukan $50 \mathrm{rpm}$ pada temperatur ruang selama 24 jam. Supernatan yang terbentuk diendapkan, dipisahkan antara endapan dan filtrat dengan proses filtrasi menggunakan kertas saring Whatman No. 40. Filtrat yang terbentuk diendapkan dengan larutan $\mathrm{HCl} 37 \%$ sampai $\mathrm{pH}$ larutan mendekati 2. Padatan dipisahkan dari filtrat melalui sentrifugasi dengan kecepatan $3500 \mathrm{rpm}$ selama 20 menit hingga dihasilkan asam humat kasar (AH Kasar).

Asam humat kasar (AH Kasar) dimurnikan dengan $1 \mathrm{~L}$ pelarut $\mathrm{KOH} 0,1 \mathrm{~N}$ dengan penambahan $10 \mathrm{~g} \mathrm{KCl}$. Campuran larutan ini diaduk dengan kecepatan pengadukan $50 \mathrm{rpm}$ pada temperatur ruang selama 24 jam. Supernatan yang terbentuk diendapkan selama 24 jam, dipisahkan antara endapan dan filtrat. Filtrat yang terbentuk diendapkan dengan $\mathrm{HCl} 37 \%$ sampai $\mathrm{pH}$ larutan mendekati 2 dengan waktu pengendapan 24 jam. Padatan dipisahkan dari filtrat melalui sentrifugasi selama 20 menit dengan kecepatan $3500 \mathrm{rpm}$. Padatan yang terbentuk dimasukkan ke dalam gelas beker yang berisi larutan campuran $0,1 \mathrm{~N} \mathrm{HCl}$ sebanyak $300 \mathrm{~mL}$ dan 0,3 N HF sebanyak $200 \mathrm{~mL}$ dan diaduk dengan kecepatan pengadukan $50 \mathrm{rpm}$ pada temperatur ruang selama 24 jam. Endapan yang diperoleh dicuci dengan akuades sampai pHnya konstan. Setelah proses pemurnian dilakukan, asam humat yang diperoleh dikeringkan di dalam oven pada temperatur $70^{\circ} \mathrm{C}$ selama 8 jam, dan dihasilkan asam humat murni (AH Murni). Kemudian padatan yang diperoleh baik $\mathrm{AH}$ Kasar maupun AH Murni dikarakterisasi dengan menggunakan instrumen analisis FTIR, XRD dan SEM.

\subsection{Proses adsorpsi timbal $(\mathrm{Pb}(\mathrm{II}))$ secara batch}

Asam humat (AH) sebagai adsorben sebanyak 50 mg dimasukkan ke dalam $50 \mathrm{~mL}$ larutan $\mathrm{Pb}$ (II) dengan konsentrasi awal 10,470 $\mathrm{mg} / \mathrm{L}$. Kemudian diaduk menggunakan magnetic stirrer dengan kecepatan pengadukan $100 \mathrm{rpm}$ selama waktu tertentu yang ditentukan pada temperatur ruang dan $\mathrm{pH}$ netral 6.7-7,0. Setelah waktu tertentu, larutan disaring dengan vacuum filter menggunakan filter kertas Whatman No. 42. Filtrat yang diperoleh dianalisis dengan (AAS) dan padatan yang tersaring di kertas saring dianalisis dengan SEM. Persentase kandungan timbal $(\mathrm{Pb})$ yang teradsorpsi dapat dihitung dengan menggunakan rumus pada persamaan (1) (Ciesielczyk dkk., 2018):

$\%$ penyerapan $=\left(\left[\mathrm{C}_{\mathrm{o}}-\mathrm{C}_{\mathrm{e}}\right] / \mathrm{W} \times \mathrm{V}\right) \times 100 \%$

dengan:

$\%$ penyerapan $=\mathrm{mg}$ logam $/$ gram adsorben, $\mathrm{C}_{\mathrm{o}}=$ konsentrasi awal timbal $(\mathrm{mg} / \mathrm{L})$,

$\mathrm{C}_{\mathrm{e}}=$ konsentrasi akhir timbal $(\mathrm{mg} / \mathrm{L})$,

$\mathrm{W}=$ massa adsorben $\mathrm{AH}(\mathrm{g})$, dan

$\mathrm{V}=$ volume larutan timbal $(\mathrm{L})$.

\section{Hasil dan Pembahasan}

\subsection{Karakterisasi asam humat}

Sayuran sebagai sumber asam humat memiliki struktur yang kompleks sehingga diperlukan tambahan perlakuan khusus untuk mengekstrak asam humat. Asam humat yang digunakan dalam penelitian ini diisolasi dari sampah sayuran pasar yang telah dikomposkan. Larutan $\mathrm{NaOH}$ diketahui sangat efektif mengekstrak senyawa asam humat, dimana senyawa asam humat larut dalam $\mathrm{NaOH}$ sedangkan senyawa bukan asam humat lainnya tidak larut (Kolla dkk., 1998). Untuk mendapatkan senyawa asam humat menggunakan larutan $\mathrm{NaOH}$ perlu ditambahkan $\mathrm{HCl}$ sehingga senyawa asam humat akan menggumpal dan tidak larut. Ekstrak asam humat kasar (AH Kasar) yang diperoleh, dimurnikan dengan melarutkan dalam larutan $\mathrm{KOH}$ dan ditambah $\mathrm{KCl}$. $\mathrm{KOH}$ dapat melarutkan asam humat dari senyawa humin lainnya dan dapat memaksimalkan kemurnian asam humat. $\mathrm{KCl}$ berfungsi sebagai penyerap air dalam pemurnian asam humat sehingga lautan menjadi lebih pekat. Proses selanjutnya adalah pencucian asam humat, hal ini dilakukan dengan cara melarutkan asam humat hasil isolasi ke dalam larutan campuran $0,1 \mathrm{~N} \mathrm{HCl}$ dan 0,3 $\mathrm{N}$ HF. Kedua pereaksi tersebut berfungsi untuk memisahkan kontaminan berupa bahan-bahan anorganik dari asam humat terutama silika dan logam (Yunitawati dkk., 2011) sehingga dihasilkan asam humat murni (AH Murni).

Spektra FTIR AH kasar dan AH Murni terlihat memiliki perbedaan seperti yang ditunjukkan pada Gambar 2. Pada AH kasar, puncak serapan yang dihasilkan pada daerah $1700 \mathrm{~cm}^{-1}$ terdapat struktur komponen aromatik vibrasi ulur untuk $\mathrm{C}=\mathrm{O}$ pada gugus karbonil dan puncak di daerah $1500 \mathrm{~cm}^{-1}$ merupakan vibrasi ulur $\mathrm{C}-\mathrm{C}$ yang berasal dari cincin aromatik. Sedangkan pada AH murni, banyak terbentuk puncakpuncak serapan baru diantaranya di daerah $3650 \mathrm{~cm}^{-1}$ merupakan vibrasi ulur untuk gugus $-\mathrm{OH}$ dan menunjukkan adanya ikatan hidrogen. Puncak serapan 
$2950 \mathrm{~cm}^{-1}$ merupakan vibrasi ulur $\mathrm{C}-\mathrm{H}$ alifatik pada alkana, serta puncak di daerah $950 \mathrm{~cm}^{-1}$ merupakan vibrasi ulur -OH yang berasal dari gugus asam karboksilat, disamping puncak di daerah $1700 \mathrm{~cm}^{-1}$ merupakan vibrasi ulur $\mathrm{C}=\mathrm{O}$ dari $\mathrm{COOH}$ dan puncak di daerah $1500 \mathrm{~cm}^{-1}$ yang merupakan vibrasi ulur $\mathrm{C}-\mathrm{C}$ yang berasal dari cincin aromatik sama seperti pada $\mathrm{AH}$ kasar (Yang dkk., 2016).

Analisis XRD dilakukan untuk mengetahui struktur amorf asam humat dari ekstrak AH kasar dan $\mathrm{AH}$ murni. Hasil difraktogram sinar X yang terlihat pada Gambar 3 menunjukkan perbedaan yang sangat jelas antara ekstrak kasar asam humat dan asam humat murni. Pada ekstrak $\mathrm{AH}$ kasar terdapat puncak karakteristik dari pengotor senyawa humin, seperti yang terlihat di Gambar 3 pada puncak $2 \Theta\left(\right.$ sekitar $32^{\circ}$ ) diduga berasal dari kontaminan anorganik, $\mathrm{SiO}_{2}(\mathrm{Si}-\mathrm{OH}, \mathrm{O}-\mathrm{H}$ bend) dalam bentuk quartz untuk $\mathrm{AH}$ kasar $0,1 \mathrm{~N} \mathrm{NaOH}$ dan $0,5 \mathrm{~N} \mathrm{NaOH}$ (Naidja dkk., 2002). Setelah dilakukan pemurnian, terdapat puncak $2 \Theta$ yang hilang, dimana hilangnya puncak $2 \Theta$ menunjukkan adanya pengotor senyawa humin, kontaminan anorganik seperti silika ( $\mathrm{Si}-\mathrm{OH} \mathrm{O}-\mathrm{H}$ bend) terlepas dari asam humat, seperti ditunjukkan pada $\mathrm{AH}$ $\begin{array}{llllllll}\text { murni } & 0,1 & \mathrm{~N} & \mathrm{NaOH} & \text { dan } & 0,5 & \mathrm{~N} & \mathrm{NaOH}\end{array}$ yang mengindikasikan berkurangnya pengotor yang terikat pada asam humat (Boguta dkk., 2019).

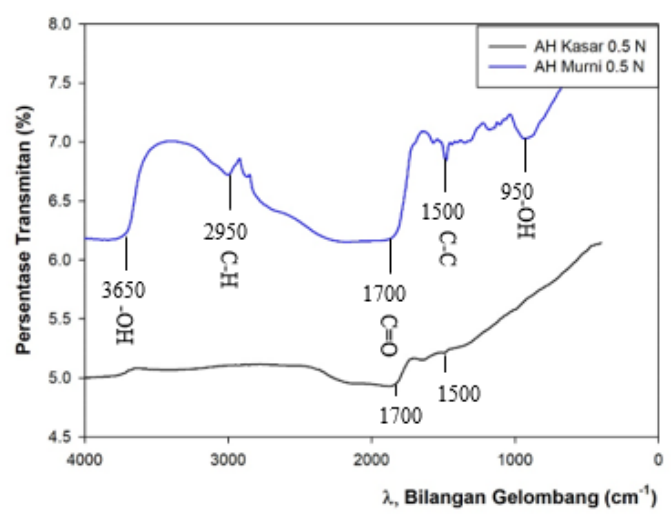

Gambar 2. Analisis FT-IR AH kasar dan AH murni dengan pelarut $0,5 \mathrm{~N} \mathrm{NaOH}$

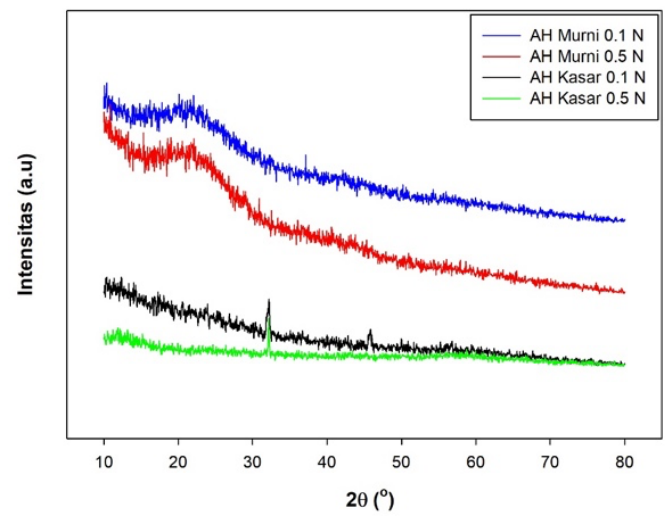

Gambar 3. X-Ray diffraction AH kasar dan AH murni pada berbagai konsentrasi ekstraktan larutan $\mathrm{NaOH}$
Hasil analisis SEM images pada pelarut $\mathrm{NaOH}$ dengan variasi $0,1 \mathrm{~N}$ dan $0,5 \mathrm{~N}$ dengan perbandingan ekstrak asam humat kasar dan asam humat murni pada Gambar 4. Struktur morfologi ekstrak AH kasar dan AH murni diobservasi dengan analisis SEM. Pada proses ekstraksi, analisis SEM diperlukan untuk mengetahui struktur morfologi asam humat. Pada Gambar 4 (a) dan (b) dapat dilihat ekstrak asam humat kasar pada pelarut $\mathrm{NaOH}$ dengan variasi $0,1 \mathrm{~N}$ dan $0,5 \mathrm{~N}$ berbentuk bongkahan dan permukaannya kasar. Hal ini karena asam humat masih diselimuti oleh senyawa humin, disamping kontaminan bahan anorganik dari asam humat terutama $\mathrm{SiO}_{2}$ (Boguta dkk., 2019; Lu dkk., 2020).

Pada Gambar 4 (c) dan (d) dapat dilihat asam humat yang sudah mengalami proses pemurnian dan pencucian, asam humat berbentuk pecahan tak beraturan dan permukaanya lebih halus. Pemurnian asam humat menggunakan pelarut $\mathrm{KOH}$ yang ditambah garam $\mathrm{KCl}$. Larutan $\mathrm{KOH}$ dapat memisahkan senyawa humin dan senyawa bukan asam humat yang terikut saat proses ekstraksi, sedangkan $\mathrm{KCl}$ berfungsi untuk mengikat molekul air yang terikat pada ekstrak kasar asam humat. Untuk mengobservasi kandungan asam humat yang dihasilkan, maka dilakukan analisis SEM-Energy Dispersive X-Ray Spectroscopy (SEM-EDS) seperti yang ditunjukkan pada Tabel 2.

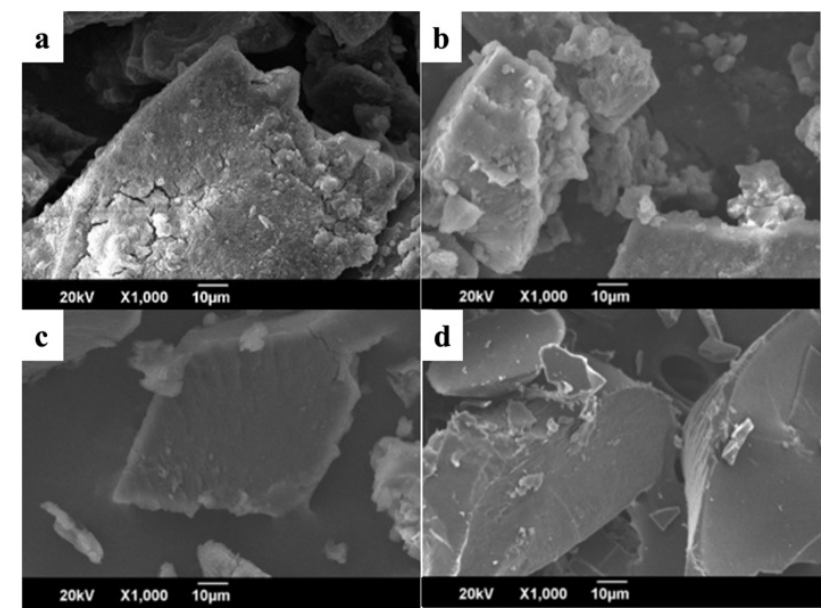

Gambar 4. SEM morfologi asam humat kasar dan asam humat murni pada berbagai konsentrasi $\mathrm{NaOH}$ (a) $\mathrm{AH}$ kasar 0,1 N NaOH (b) AH kasar 0,5 N NaOH (c) $\mathrm{AH}$ murni 0,1 N NaOH (d) AH murni 0,5 N NaOH

Tabel 2. Komposisi AH kasar 0,1 N NaOH dan $\mathrm{AH}$ murni $0,1 \mathrm{~N} \mathrm{NaOH}$ berdasarkan EDS analisis

\begin{tabular}{ccc}
\hline \multirow{2}{*}{ Komponen } & \multicolumn{2}{c}{ Kandungan (\% berat) } \\
\cline { 2 - 3 } & AH Kasar & AH Murni \\
\hline $\mathrm{C}$ & 51,71 & 66,61 \\
$\mathrm{O}$ & 18,40 & 27,03 \\
$\mathrm{Al}$ & 3,10 & - \\
$\mathrm{Si}$ & 6,57 & - \\
$\mathrm{S}$ & 2,76 & - \\
$\mathrm{Cl}$ & 17,46 & - \\
$\mathrm{Mg}$ & - & 0,86 \\
$\mathrm{Ca}$ & - & 5,50 \\
\hline
\end{tabular}


Analisis ini untuk mengetahui komposisi yang terkandung dalam ekstrak asam humat kasar dan asam humat murni. Analisis EDS dapat mengetahui perbedaan komposisi yang terkandung dari ekstrak kasar AH 0,1 N $\mathrm{NaOH}$ dan $\mathrm{AH}$ murni $0,1 \mathrm{~N} \mathrm{NaOH}$. Adanya kandungan $\mathrm{C}$ dan $\mathrm{O}$ pada kedua sampel menunjukkan bahwa asam humat mengandung karbon dan oksigen yang merupakan bahan penyusun makromolekul polielektrolit yang memiliki gugus fungsional seperti karboksil, $-\mathrm{COOH}$ (Yang dkk., 2015).

\subsection{Proses adsorpsi timbal $(\mathrm{Pb}(\mathrm{II}))$ secara batch} dengan asam humat sebagai adsorben

Waktu kesetimbangan proses penghilangan timbal ditentukan dengan melakukan percobaan pada temperatur ruang, konsentrasi timbal awal sekitar $10,5 \mathrm{mg} / \mathrm{L}$, dosis adsorben $1 \mathrm{~g} / \mathrm{L}$, kecepatan pengadukan $150 \mathrm{rpm}, \mathrm{pH}$ 6,77,0 pada berbagai waktu kontak. Gambar 5 menunjukkan bahwa sejumlah besar timbal teradsorpsi dalam 10 menit pertama, setelah itu adsorpsi timbal meningkat secara perlahan hingga waktu kesetimbangan tercapai. Waktu kesetimbangan adalah 1 jam. Adsorpsi ion logam seperti timbal, tembaga, kromium dan besi pada asam humat merupakan proses yang cepat seperti yang dilaporkan dalam beberapa penelitian sebelumnya (Yunitawati dkk., 2011; Scaglia dkk., 2013; Qi dkk., 2017; Boguta dkk., 2019; Xu dkk., 2021). Waktu ekuilibrium proses penghilangan timbah oleh AH Murni $0.1 \mathrm{~N} \mathrm{NaOH}$ sekitar 1 jam dipilih untuk percobaan lebih lanjut untuk memastikan bahwa sistem sudah dalam kondisi ekuilibrium.

Gambar 5 menunjukkan bahwa selama 30 menit pertama, kapasitas penyerapan timbal meningkat secara signifikan dari $0 \mathrm{mg} / \mathrm{g}$ menjadi $10,15 \mathrm{mg} / \mathrm{g}$, yang mungkin disebabkan oleh difusi yang terjadi ke dalam pori-pori dan adsorpsi ke permukaan adsorben. Awalnya, gradien konsentrasi timbal $(\mathrm{Pb}(\mathrm{II}))$ relatif tinggi yang memfasilitasi difusi cepat ke dalam dan melalui pori $\mathrm{AH}$ Murni 0,1 N. Kemudian kapasitas serapan timbal sedikit meningkat mencapai kapasitas serapan timbal sebesar $10,35 \pm 0,1 \mathrm{mg} / \mathrm{g}$ dan konstan mencapai kondisi kesetimbangan dalam waktu 1 jam.

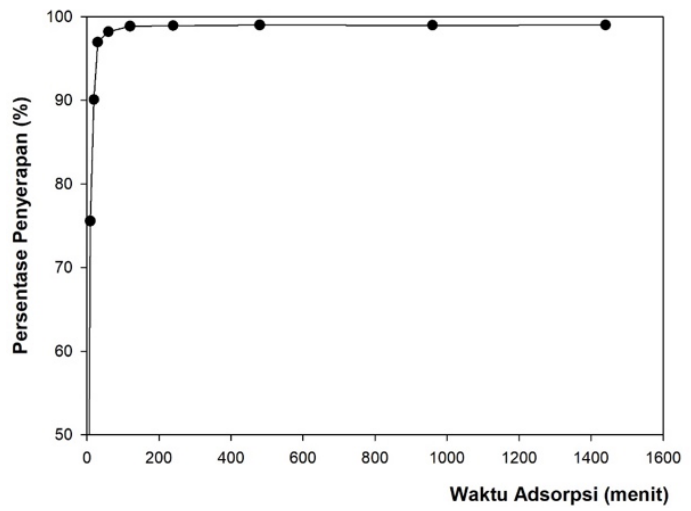

Gambar 5. Persentase penyerapan ion timbal ( $\mathrm{Pb}(\mathrm{II})$ ) sesudah adsorpsi pada berbagai waktu kontak pada temperatur ruang, massa adsorben $\mathrm{AH}$ murni $0,1 \mathrm{~N}$ $\mathrm{NaOH} 1 \mathrm{~g} / \mathrm{L}, \mathrm{pH}$ 6,7-7,0, pengadukan $150 \mathrm{rpm}$

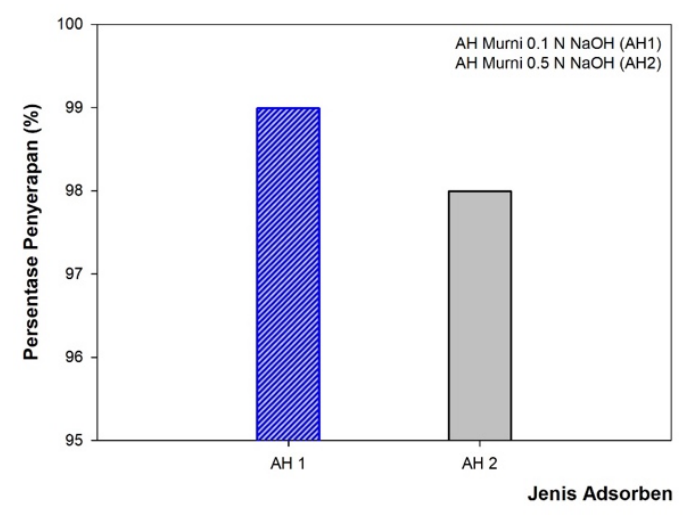

Gambar 6. Persentase penyerapan ion timbal ( $\mathrm{Pb}(\mathrm{II})$ ) sesudah adsorpsi menggunakan AH Murni 0,1 N NaOH dan $\mathrm{AH}$ murni $0,5 \mathrm{~N} \mathrm{NaOH}$ pada temperatur ruang, massa adsorben $1 \mathrm{~g} / \mathrm{L}, \mathrm{pH}$ 6,7-7,0, kecepatan pengadukan $150 \mathrm{rpm}$, waktu adsorpsi 1 jam

Dari hasil pengujian proses adsorpsi pada limbah cair sintesis $\mathrm{Pb}$ (II) seperti yang terlihat pada Gambar 6 diperoleh konsentrasi $\mathrm{Pb}$ (II) sesudah proses adsorpsi selama 1 jam sekitar $0,12 \mathrm{mg} / \mathrm{L}$, dengan persentase penyerapan mencapai 98,8\% untuk AH Murni 0,1 N dan $0,22 \mathrm{mg} / \mathrm{L}$ dengan persentase penyerapan mencapai 97,9\% untuk $\mathrm{AH}$ murni $0,5 \mathrm{~N} \mathrm{NaOH}$.

Dari analisis EDS seperti yang tertera pada Tabel 3 kandungan $\mathrm{Pb}$ (II) pada $\mathrm{AH}$ murni dengan pelarut $0,1 \mathrm{~N}$ $\mathrm{NaOH}$ yaitu $10,22 \%$ lebih banyak dari $\mathrm{AH}$ murni dengan pelarut $0,5 \mathrm{~N} \mathrm{NaOH}$ yaitu hanya 7,67\%. Ekstraktan dengan menggunakan larutan $0,1 \mathrm{~N} \mathrm{NaOH}$ lebih sering digunakan karena sifat ekstraksinya yang tidak terlalu kuat dibanding larutan $0,5 \mathrm{~N} \mathrm{NaOH}$, serta $\mathrm{Pb}$ (II) lebih banyak terserap pada $\mathrm{AH}$ murni $0,1 \mathrm{~N} \mathrm{NaOH}$ dikarenakan lebih banyak memiliki gugus karboksil (Kolla dkk., 1998; Yang dkk., 2015). Proses adsorpsi terhadap $\mathrm{Pb}$ (II) dengan menggunakan AH murni sebagai adsorben juga terlihat dari analisis EDS pada Tabel 3 jika dibandingkan dengan Tabel 2 yang tidak mengandung $\mathrm{Pb}$ (II) sebelum proses adsorpsi dilakukan.

Dari Gambar 7 (a) dan (b) dapat terlihat bahwa setelah adsorpsi terdapat timbal $(\mathrm{Pb})$ yang menempel pada serat asam humat. Proses pengikatan ini akan membuat luas permukaan asam humat lebih besar sehingga lebih efektif digunakan sebagai adsorben. Untuk mengobservasi kandungan asam humat yang dihasilkan, maka dilakukan analisis EDS. Analisis ini untuk mengetahui komposisi yang terkandung dalam asam humat setelah proses adsorpsi. Hasil yang ditunjukkan dari Gambar 7 tersebut juga menunjukkan analisis EDS pada adsorben asam humat setelah proses adsorpsi. Dari gambar dapat diketahui perbedaan komposisi yang terkandung dari $\mathrm{AH}$ setelah proses adsorpsi menggunakan $\mathrm{AH}$ murni dengan pelarut $0,1 \mathrm{~N}$ $\mathrm{NaOH}$ dan $0,5 \mathrm{~N} \mathrm{NaOH}$. Adanya peak timbal (Pb (II)) pada asam humat setelah proses adsorpsi menunjukkan bahwa $\mathrm{Pb}$ (II) berhasil diikat oleh asam humat. Perbedaan kandungan $\mathrm{Pb}$ (II) pada kedua asam humat menunjukkan kemampuan adsorpsi pada asam humat sebagai adsorben. 
Tabel 3. Komposisi AH Murni 0,1 N NaOH dan $\mathrm{AH}$ Murni $0,5 \mathrm{NaOH}$ setelah proses adsorpsi

\begin{tabular}{ccc}
\hline \multirow{3}{*}{ Komponen } & \multicolumn{2}{c}{ Kandungan (\% berat) } \\
\cline { 2 - 3 } & $\begin{array}{c}\text { AH Murni 0,1 N } \\
\text { NaOH }\end{array}$ & $\begin{array}{c}\text { AH Murni } \\
0,5 \text { N NaOH }\end{array}$ \\
\hline $\mathrm{C}$ & 60,15 & 60,65 \\
$\mathrm{O}$ & 29,63 & 31,68 \\
$\mathrm{~Pb}$ & 10,22 & 7,67 \\
\hline
\end{tabular}

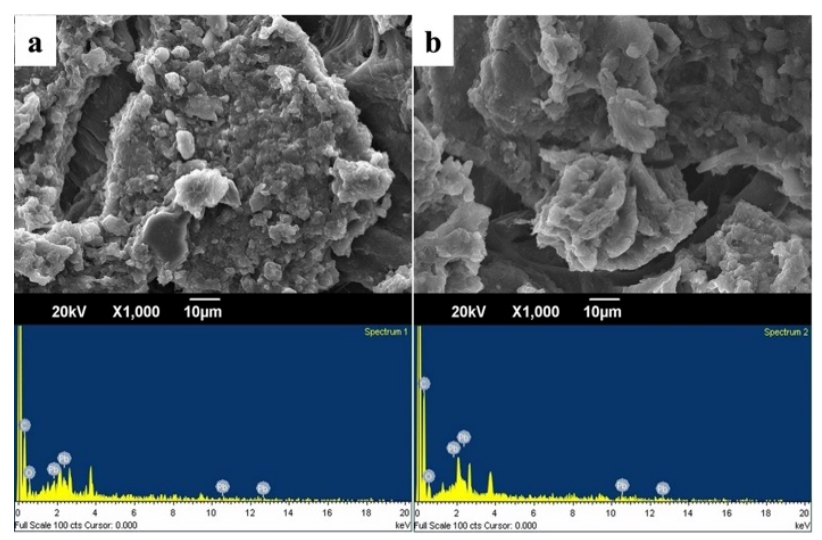

Gambar 7. SEM images dan EDS analisis dari asam humat setelah proses adsorpsi menggunakan (a) $\mathrm{AH}$ murni $0,1 \mathrm{~N} \mathrm{NaOH}$ (b) AH murni 0,5 N NaOH

\section{Kesimpulan}

Beberapa kesimpulan yang diperoleh dari hasil penelitian yang dilakukan terhadap karakteristik asam humat yang dihasilkan diantaranya dari analisis FTIR menunjukkan pada ekstrak $\mathrm{AH}$ kasar terdapat gugus karbonil, sedangkan pada $\mathrm{AH}$ murni terdapat ikatan hidrogen, ikatan alifatik pada alkana, gugus karboksilat, cincin aromatik, serta gugus asam karboksilat. Analisis XRD menunjukkan pada ekstrak $\mathrm{AH}$ kasar terdapat kontaminan anorganik seperti $\mathrm{SiO}_{2}$ di daerah $2 \Theta$ (sekitar $32^{\circ}$ ). Analisis SEM-EDS disamping melihat morfologi ekstrak AH kasar berbentuk bongkahan dan permukaannya kasar, dan asam humat murni permukaannya pecahan tak beraturan dan permukaanya lebih halus. Disamping itu SEM-EDS mengetahui komposisi yang terkandung dalam ekstrak AH kasar dan AH murni, dimana pada $\mathrm{AH}$ kasar asam humat masih diselimuti oleh senyawa humin, juga kontaminan bahan anorganik dari asam humat terutama $\mathrm{SiO}_{2}$.

Proses pengolahan adsorben asam humat dari sampah sayuran pasar menggunakan metode ekstraksi dengan variasi pelarut $\mathrm{NaOH}$ yaitu $0,1 \mathrm{~N}$ dan $0,5 \mathrm{~N}$ dengan keefektifan kapasitas adsorpsi terhadap penyerapan logam $\mathrm{Pb}$ (II) masing-masing mencapai $98,8 \%$ dan $97,9 \%$. Asam humat dapat berperan sebagai media adsorben untuk menurunkan konsentrasi timbal pada limbah cair sintesis $\mathrm{Pb}$ (II) yang ditunjukkan dari analisis EDS asam humat setelah adsorpsi terdapat timbal $(\mathrm{Pb})$ yang menempel pada serat asam humat.

\section{Ucapan Terima Kasih}

Terima kasih penulis ucapkan kepada Fakultas Teknik Universitas Lambung Mangkurat yang telah mendukung kegiatan penelitian ini sehingga dapat terselesaikan dengan baik.

\section{Daftar Pustaka}

Boguta, P.; D'Orazio, V.; Senesi, N.; Sokołowska, Z.; Szewczuk-Karpisz, K., Insight Into the Interaction Mechanism of Iron Ions with Soil Humic Acids. The Effect of The $\mathrm{pH}$ and Chemical Properties of Humic Acids. Journal of Environmental Management, 2019, 245, 367-374.

Boguta, P.; D'Orazio, V.; Sokołowska, Z.; Senesi, N., Effects of Selected Chemical and Physicochemical Properties of Humic Acids from Peat Soils on their Interaction Mechanisms with Copper Ions at Various pHs. Journal of Geochemical Exploration, 2016, 168, 119-126.

Ciesielczyk, F.; Goscianska, J.; Zdarta, J.; Jesionowski, T., The Development of Zirconia/Silica Hybrids for the Adsorption and Controlled Release of Active Pharmaceutical Ingredients. Colloids and Surfaces A: Physicochemical and Engineering Aspects, 2018, 545, 39-50.

de Melo, B.A.G.; Motta, F.L.; Santana, M.H.A., Humic Acids: Structural Properties and Multiple Functionalities for Novel Technological Developments. Materials Science and Engineering: C, 2016, 62, 967-974.

Hayes, M.H.B., Humic Substances: Progress Towards More Realistic Concepts of Structures. Davies, G.; Ghabbour, E.A., eds., Humic Substances: Structures, Properties, and Uses. Cambridge: The Royal Society of Chemistry, 1998, pp. 1-27.

Hu, J.; Wu, J.; Qu, X.; Li, J., Effects of Organic Wastes on Structural Characterizations of Humic Acid in Semiarid Soil under Plastic Mulched Drip Irrigation. Chemosphere, 2018, 200, 313-321.

Kementerian Lingkungan Hidup Republik Indonesia, Peraturan Menteri Lingkungan Hidup Nomor 5 Tahun 2014 tentang Baku Mutu Air Limbah, 2014.

Kolla, S.; Paciolla, M.D.; Sein, L.T.; Moyer, J.; Walia, D.; Heaton, H.; Jansen, S.A., Humic Acid As A substrate for Alkylation. Davies, G.; Ghabbour, E.A. eds., Humic Substances: Structures, Properties, and Uses. Cambridge: The Royal Society of Chemistry, 1998, pp. 215-225.

Li, L.; Huang, W.; Peng, P.A.; Sheng, G.; Fu, J., Chemical and Molecular Heterogeneity of Humic Acids Repetitively Extracted from A Peat. Soil Science Society of America Journal, 2003, 67, 740-746. 
Lu, Y.; Liang, Y.; Liu, F.; Wang, Z.; Shi, Z., Nano Scale Visualization of Enhanced Adsorption and Distribution of Humic Acid on Hematite: Effect of $\mathrm{Pb}(\mathrm{II})$ Ions. Chemical Geology, 2020, 541, 119573.

Mao, J.; Hu, W.; Schmidt-Rohr, K.; Davies, G.; Ghabbour, E.A.; Xing, B., Structure and Elemental Composition of Humic Acids: Comparison of Solid-State ${ }^{13} \mathrm{C}$ NMR Calculations and Chemical Analyses. Davies, G.; Ghabbour, E.A. eds., Humic Substances: Structures, Properties, and Uses. Cambridge: The Royal Society of Chemistry, 1998, pp. 79-90.

Naidja, A.; Huang, P.M.; Anderson, D.W.; Van Kessel, C., Fourier Transform Infrared, UV-Visible, and X-Ray Diffraction Analyses of Organic Matter in Humin, Humic Acid, and Fulvic Acid Fractions in Soil Exposed to Elevated $\mathrm{CO}_{2}$ and $\mathrm{N}$ Fertilization. Applied Spectroscopy, 2002, 56, 318-324.

Peña-Méndez, E.; Havel, J.; Patocka, J., Humic Substances-Compounds of Still Unknown Structure: Applications in Agriculture, Industry, Environment, and Biomedicine. Journal of Applied Biomedicine, 2005, 3, 13-24.

Qi, Y.; Zhu, J.; Fu, Q.; Hu, H.; Huang, Q., Sorption of $\mathrm{Cu}$ by Humic Acid from The Decomposition of Rice Straw in The Absence and Presence of Clay Minerals. Journal of Environmental Management, 2017, 200, 304 311.
Scaglia, B.; Tambone, F.; Adani, F., Cr(VI) Reduction Capability of Humic Acid Extracted from the Organic Component of Municipal Solid Waste. Journal of Environmental Sciences, 2013, 25, 487-494.

Xu, H.; Hu, X.; Chen, Y.; Li, Y.; Zhang, R.; Tang, C.; $\mathrm{Hu}, \mathrm{X} ., \mathrm{Cd}(\mathrm{II})$ and $\mathrm{Pb}$ (II) Absorbed on Humic Acid-IronPillared Bentonite: Kinetics, Thermodynamics and Mechanism of Adsorption. Colloids and Surfaces A: Physicochemical and Engineering Aspects, 2021, 612, 126005.

Yang, K.; Miao, G.; Wu, W.; Lin, D.; Pan, B.; Wu, F.; Xing, B., Sorption of $\mathrm{Cu}^{2+}$ on Humic Acids Sequentially Extracted from a Sediment. Chemosphere, 2015, 138, 657-663.

Yang, L.; Wei, Z.; Zhong, W.; Cui, J.; Wei, W., Modifying Hhydroxyapatite Nanoparticles with Humic Acid for Highly Efficient Removal of $\mathrm{Cu}(\mathrm{II})$ from Aqueous Solution. Colloids and Surfaces A: Physicochemical and Engineering Aspects, 2016, 490, 921.

Yunitawati; Nurmasari, R.; Mujiyanti, D.R.; Umaningrum, D., Kajian $\mathrm{pH}$ dan Waktu Kontak Optimum Adsorpsi Cd(II) dan Zn(II) pada Humin. Sains dan Terapan Kimia, 2011, 5(2), 151-157. 